\title{
SYSTEMATIC REVIEW FOR MANAGEMENT OF POSTEROLATERAL CORNER INJURIES OF THE KNEE
}

\author{
Ahmed M. Elsaeed MD, Amr A. Abdelrahman MD, Ahmed K. Mohamed Meselhy M.B., B. Ch., \\ Department of Orthopedic Surgery, Faculty of Medicine, Ain Shams University.
}

Corresponding Auther

Ahmed K. Mohamed Meselhy

Mobil: 01008980969

emil:

dr.a.meselhy@hotmail.com

\begin{abstract}
Background: There is a paucity of outcome data to guide the surgical treatment of posterolateral corner knee injuries.

Purpose: To systematically review the literature to compare clinical outcomes of the treatment PLC injuries.

Study Design: Systematic review; Level of evidence, 4.

Methods: A systematic review of the literature including PubMed was performed. The following search terms were used: "posterolateral corner", "chronic PLC injuries" "acute PLC injuries" and "repair of PLC injuries", "reconstruction of PLC". Inclusion criteria were: Human examinations and treatment, measures of functional and clinical outcome included, exclusion criteria were: Non English papers, Non-human trials, Articles with no clinical data.
\end{abstract}

Results: Eighteen studies with a total of 559 patients were included. When time to surgery was performed within 6 weeks it is considered acute injury while on the other hand more than that was considered chronic injury. Surgical treatment varied between repair and reconstruction there was an overall success rate of repair $75 \%$ and failure rate of $25 \%$ and overall success rate of reconstruction was $91 \%$ and $9 \%$ failure rate.

Surgical techniques: 83 patients underwent repair for the PLC while 476 patients underwent reconstruction for the PLC, surgical techniques varied among studies, between repair and reconstruction techniques which was different between studies, including fibular sling using one femoral tunnel or two femoral tunnels, posterolateral capsular shift trying to increase rotational stability, anatomic PLC reconstruction, biceps tenodesis and isometric reconstruction of the FCL and the popliteus with a single graft.

Conclusion: The repair of acute PLC injuries and staged treatment of combined cruciate injuries were associated with a substantially higher postoperative PLC failure rate than reconstruction. Further research is required to identify the reconstruction technique that provides optimal subjective and objective outcomes.

Key words: posterolateral corner, chronic PLC injuries, acute PLC injuries and repair of PLC injuries, reconstruction of PLC.

\section{INTRODUCTION}

$\mathbf{P}$ osterolateral corner lesions have been estimated to occur in $9.1 \%$ of acute knee injuries with haemarthrosis and $16 \%$ of all knee ligament injuries, often presenting with concomitant anterior cruciate ligament or posterior cruciate ligament or both, isolated PLC has shown to account for less than $30 \%$ of the injuries, failure to detect these injuries has been shown to be an important cause of recurrent instability and failed cruciate ligament reconstructions ${ }^{[1]}$.

The main structures that make up the PLC of the knee are the lateral collateral ligament, popliteus tendon, popliteo-fibular ligament, and lateral knee capsule ${ }^{[2]}$ (Fig. 1). 


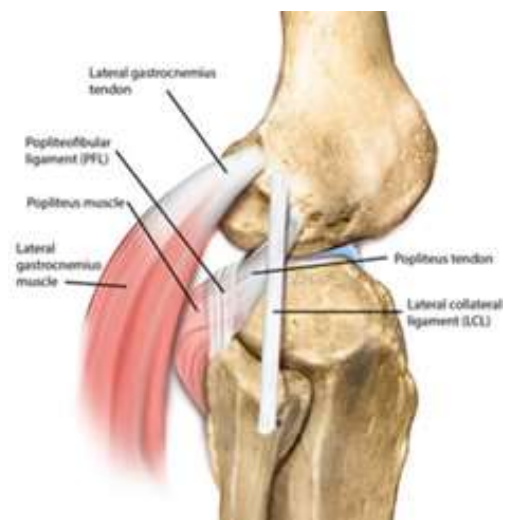

Fig. (1) Illustration demonstrating anatomy and relationships of the FCL, popliteus tendon, PFL, and lateral gastrocnemius tendon (lateral view of a right knee) ${ }^{[3]}$.

In the past, although also once considered to be the "dark side of the knee", treatment of lateral side instability has been challenging due to limited data on the anatomy and biomechanics of the PLC structures and under-reporting of clinical outcomes following non-operative and operative treatment. However, more recently, the anatomy and biomechanics have become well-defined and good outcomes have been reported after PLC operative treatment following anatomic reconstruction principles [4].

Although there are several operative techniques for management of PLC injuries but none of these techniques has been standardized [5].

\section{MATERIALS AND METHODS}

Online search was done using the midline database on PUBMED from 2006 to 2016, all the English language published studies will be identified with the search keywords of "posterolateral corner", "chronic PLC injuries" "acute PLC injuries" and "repair of PLC injuries", "reconstruction of PLC". Literature search database on PUBMED showed 399 studies. 1ry screening: 295 studies were excluded due to language other than English language and other topics not related to search goals.

2ry screening: Title or abstract review 78 studies excluded due to cadaveric studies and duplicates.

3ry screening: Full text review was done and 8 articles were excluded due to lack of functional outcome and case reports. 18 studies were included.

PRISMA (Preferred Reporting Items for Systematic Reviews and Meta-Analysis) flow diagram for study selection was used.

\section{Inclusion criteria:}

Studies which are included in our systematic review met the following guidelines:

1) They provided levels I to IV evidence in one of the 3 areas of interest or more outlined previously.

2) Human examinations and treatment.

3) They included measures of functional and clinical outcome.

\section{Exclusion criteria:}

1) Non English papers.

2) Non-human trials.

3) Articles with no clinical data. 


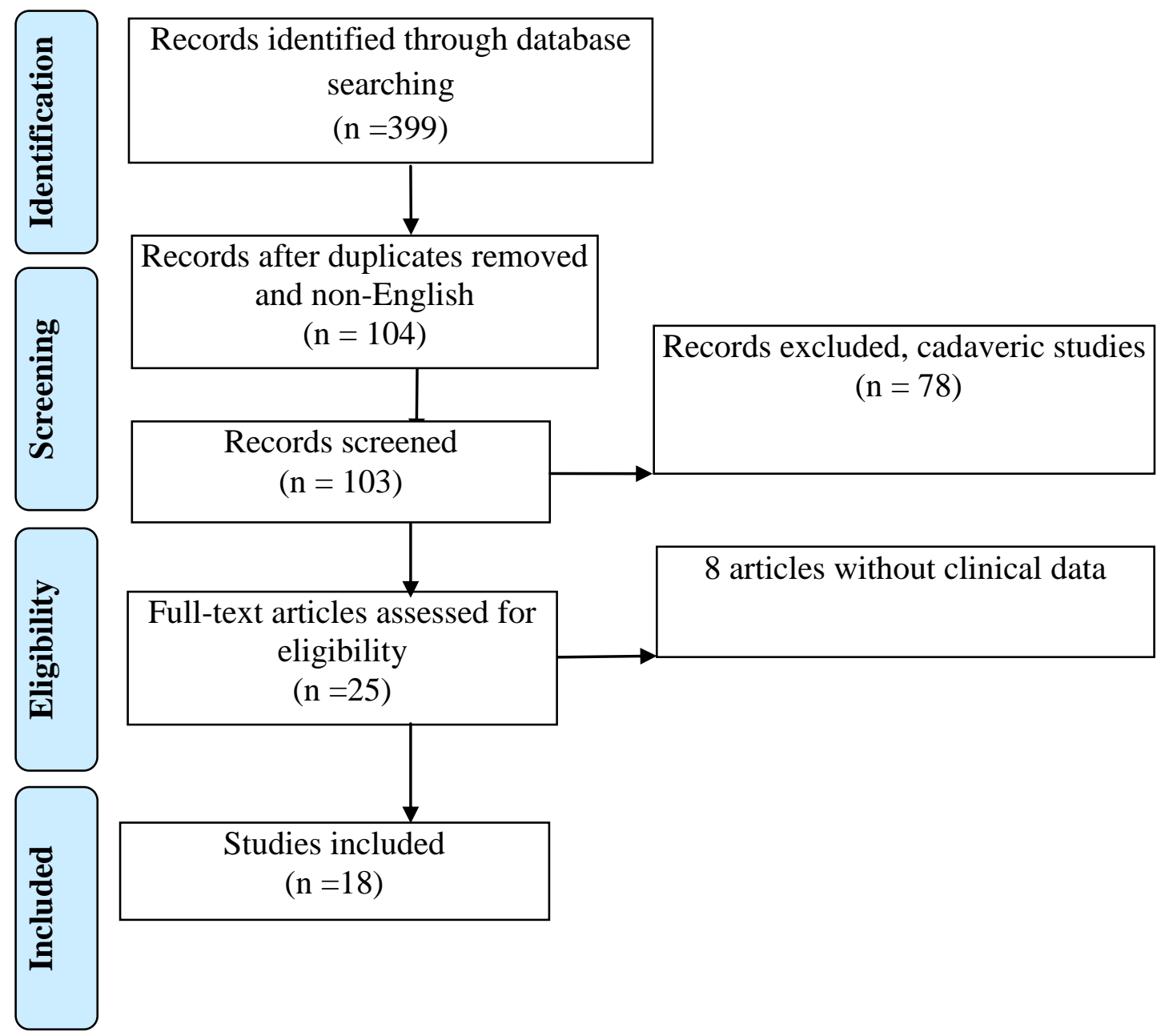

\section{Data collection:}

Patients demographics, surgical technique, duration of follow up, subjective outcomes (Lysholm scores, IKDC) and objective outcome (varus stress examination, varus stress radiographs) mean were recorded.

Lysholm and IKDC scores were chosen because it is the most widely reported subjective outcome for PLC injuries.

Post-operative varus examination and radiographic findings were collected and classified as success or failure.

Success was defined as grade 0 or I.

Failure was defined as grade II or III postoperative or the need to reoperate because of varus instability.

\section{RESULTS}

Our search revealed 18 studies accounting for total of 559 patients included in the final analysis (Table 1).

Acute cases: Ibrahim et al, Geeslin and LaPrade, McCarthy et al (18 cases) Schechinger et al (7 cases), Levy et al.

Chronic cases: McCarthy et al (43 cases), Schechinger et al ( 9 cases), Fanelli et al, Kim et al (2013, 2012, 2011 and 2010), Zorzi et al Noyes et al (2011 and 2007) al Yoon et al Jakobson et al LaPrade et al.

Different surgical techniques were used in the studies shown in table (2). 
Table (1) showing list of, papers no. of patients, time to surgery, mean follow up time and age of patients.

\begin{tabular}{|c|c|c|c|c|c|c|}
\hline Author & Study no. & $\begin{array}{c}\text { No. of } \\
\text { patients }\end{array}$ & Year & $\begin{array}{l}\text { Time to } \\
\text { surgery }\end{array}$ & $\begin{array}{l}\text { Mean follow } \\
\text { up (months) }\end{array}$ & Age (years) \\
\hline$\underset{[10]}{\text { Shelbourne et al }}$ & 1 & 21 & 2007 & $\begin{array}{l}4-41 \\
\text { days }\end{array}$ & 48 & $\begin{array}{c}21 \\
(16-31)\end{array}$ \\
\hline Noyes et al ${ }^{[19]}$ & 2 & 14 & 2007 & $\begin{array}{l}2-198 \\
\text { months }\end{array}$ & 72 & $\begin{array}{c}27 \\
(15-43)\end{array}$ \\
\hline Bin and Nam ${ }^{[11]}$ & 3 & 8 & 2007 & $\begin{array}{l}2-14 \\
\text { days }\end{array}$ & 48 & $\begin{array}{c}30 \\
(20-51) \\
\end{array}$ \\
\hline Schechinger et al & 4 & $\begin{array}{c}\text { Chronic } 9 \\
\text { Acute } 7\end{array}$ & 2009 & $\begin{array}{c}\text { Chronic 2- } \\
190 \text { months } \\
\text { Acute } 17-30 \\
\text { days }\end{array}$ & 30 & $\begin{array}{c}30 \\
(20-53)\end{array}$ \\
\hline Levy et al $^{[5]}$ & 5 & $\begin{array}{l}\text { Chronic } 18 \\
\text { Acute } 10\end{array}$ & 2010 & $\begin{array}{c}\text { Chronic 5-20 } \\
\text { months } \\
20-45 \\
\text { days }\end{array}$ & 35 & Not recorded \\
\hline Kim et al ${ }^{[16]}$ & 6 & 42 & 2010 & $\begin{array}{c}5-48 \\
\text { months }\end{array}$ & 48 & $\begin{array}{c}31 \\
(20-48) \\
\end{array}$ \\
\hline Jakobson et al $^{[21]}$ & 7 & 27 & 2010 & $\begin{array}{c}5-78 \\
\text { months }\end{array}$ & 48 & $\begin{array}{c}28 \\
(13-57) \\
\end{array}$ \\
\hline LaPrade et al ${ }^{[22]}$ & 8 & 64 & 2010 & $\begin{array}{c}2-144 \\
\text { months }\end{array}$ & 32 & $\begin{array}{c}32 \\
(18-58)\end{array}$ \\
\hline $\begin{array}{l}\text { Geeslin and } \\
\text { LaPrade }^{[7]} \\
\end{array}$ & 9 & 26 & 2011 & $\begin{array}{l}3-42 \\
\text { days }\end{array}$ & 28 & $\begin{array}{c}27 \\
(16-63) \\
\end{array}$ \\
\hline Kim et al ${ }^{[15]}$ & 10 & 46 & 2011 & $\begin{array}{c}4-27 \\
\text { months }\end{array}$ & 24 & $\begin{array}{c}35 \\
(19-60) \\
\end{array}$ \\
\hline Noyes et al ${ }^{[18]}$ & 11 & 13 & 2011 & $\begin{array}{c}3-108 \\
\text { months }\end{array}$ & 72 & $\begin{array}{c}25 \\
(15-43)\end{array}$ \\
\hline Yoon et al ${ }^{[20]}$ & 12 & 32 & 2011 & $\begin{array}{c}2-95 \\
\text { months }\end{array}$ & 36 & $\begin{array}{c}35 \\
(20-54)\end{array}$ \\
\hline Kim et al ${ }^{[14]}$ & 13 & 23 & 2012 & $\begin{array}{c}2-30 \\
\text { months }\end{array}$ & 24 & $\begin{array}{c}36 \\
(21-53) \\
\end{array}$ \\
\hline Ibrahim et al $^{[6]}$ & 14 & 20 & 2013 & $\begin{array}{c}15-21 \\
\text { days }\end{array}$ & 42 & $\begin{array}{c}26.4 \\
(18-48)\end{array}$ \\
\hline Kim et al ${ }^{[13]}$ & 15 & 65 & 2013 & $\begin{array}{c}5-48 \\
\text { months }\end{array}$ & 32 & $\begin{array}{c}37 \\
(16-64) \\
\end{array}$ \\
\hline Zorzi et al ${ }^{17]}$ & 16 & 19 & 2013 & $\begin{array}{c}5-122 \\
\text { months }\end{array}$ & 36 & $\begin{array}{c}29 \\
(17-41) \\
\end{array}$ \\
\hline Fanelli et al ${ }^{[12]}$ & 17 & 34 & 2014 & $\begin{array}{c}2-48 \\
\text { months }\end{array}$ & 30 & $\begin{array}{c}27 \\
(15-53)\end{array}$ \\
\hline McCarthy et $\mathrm{al}^{[8]}$ & 18 & $\begin{array}{l}\text { Chronic } 43 \\
\text { Acute } 18\end{array}$ & 2015 & $\begin{array}{c}\text { Chronic } 4-90 \\
\text { months } \\
\text { Acute } 15-40 \\
\text { days }\end{array}$ & $\begin{array}{c}\text { Chronic } 38 \\
\text { Acute } 42\end{array}$ & $\begin{array}{c}33 \\
(21-58)\end{array}$ \\
\hline
\end{tabular}


Table (2) Showing surgical techniques for each study

\begin{tabular}{|c|c|}
\hline Author & PLC repair or reconstruction technique \\
\hline Ibrahim et al (2013) & Fibular sling with a single femoral fixation point \\
\hline $\begin{array}{l}\text { Geeslin and } \\
\text { LaPrade (2011) }\end{array}$ & $\begin{array}{l}\text { Anatomic reconstruction of midsubstanace FCL and popliteus tendon } \\
\text { injuries, and direct repair of lateral capsule avulsion with suture anchors and } \\
\text { repaired popliteus tendon bony avulsions. }\end{array}$ \\
\hline $\begin{array}{l}\text { McCarthy et al } \\
(2015)\end{array}$ & $\begin{array}{l}\text { For the chronic group reconstruction with fibular sling with } 2 \text { femoral } \\
\text { tunnels was done. } \\
\text { For the acute group direct repair of FCL and popliteus tendon injuries with } \\
\text { suture anchors. }\end{array}$ \\
\hline Levy et al (2010) & $\begin{array}{l}\text { For the chronic group reconstruction with fibular sling with a single femoral } \\
\text { fixation point. } \\
\text { For the acute group direct repair of FCL and popliteus tendon injuries with } \\
\text { suture anchors and posterolateral capsule reefing. }\end{array}$ \\
\hline $\begin{array}{l}\text { Scechinger et al } \\
(2009)\end{array}$ & $\begin{array}{l}\text { Reconstruction with fibular sling with } 2 \text { femoral tunnels and performed } \\
\text { posterolateral capsule imbrication. }\end{array}$ \\
\hline $\begin{array}{l}\text { Shelbourne et al } \\
(2007)\end{array}$ & $\begin{array}{l}\text { Performed "en masse surgical repair" of the healing lateral structures to the } \\
\text { tibia using a staple (with possible separate repair of biceps femoris tendon } \\
\text { to the fibula). }\end{array}$ \\
\hline Bin and Nam (2007) & $\begin{array}{l}\text { Direct repair of fibular collateral ligament and popliteus tendon injuries } \\
\text { with suture anchors and posterolateral capsule reefing. }\end{array}$ \\
\hline Fanelli et al (2014) & Fibular sling with a single figure of eight graft and capsular imbrication. \\
\hline Kim et al (2013) & $\begin{array}{l}\text { Isometric reconstruction of the FCL and the popliteus with a single graft, } \\
\text { recreating the anterior tibiofibular ligament. }\end{array}$ \\
\hline Kim et al (2012) & $\begin{array}{l}\text { Isometric reconstruction of the FCL and the popliteus with a single graft, } \\
\text { recreating the anterior tibiofibular ligament. }\end{array}$ \\
\hline Kim et al (2011) & $\begin{array}{l}21 \text { patient Isometric reconstruction of the FCL and the popliteus with a } \\
\text { single graft, recreating the anterior tibiofibular ligament (Group A), } 25 \\
\text { patient biceps rerouting tenodesis (Group B). }\end{array}$ \\
\hline Kim et al (2010) & $\begin{array}{l}\text { Isometric reconstruction of the FCL and the popliteus with a single graft, } \\
\text { recreating the anterior tibiofibular ligament. }\end{array}$ \\
\hline Zorzi et al (2013) & Fibular sling, single femoral fixation point. \\
\hline Noyes et al (2011) & Femoral-fibular-looped FCL reconstruction with capsular imbrication. \\
\hline Noyes et al (2007) & Bone-Patellar tendon-Bone FCL reconstruction. \\
\hline Yoon et al (2011) & $\begin{array}{l}\text { Single fibular sling with } 2 \text { femoral tunnels "anatomic reconstruction" } \\
\text { involves a fibular sling with anatomic popliteal tendon reconstruction. }\end{array}$ \\
\hline $\begin{array}{l}\text { Jakobson et al } \\
(2010)\end{array}$ & $\begin{array}{l}\text { Fibular sling with } 2 \text { femoral tunnels and secondary graft, recreating the } \\
\text { popliteus tendon and PFL. }\end{array}$ \\
\hline $\begin{array}{l}\text { LaPrade et al } \\
\text { (2010) }\end{array}$ & Anatomic reconstruction of FCL, popliteus and PFL. \\
\hline
\end{tabular}

Outcomes:

Post-operative Lysholm score, IKDC was documented in table (4) 
Table (3) Post-operative Lysholm score and IKDC

\begin{tabular}{|c|c|c|}
\hline Author & $\begin{array}{c}\text { Mean } \\
\text { Lysholm }\end{array}$ & Mean IKDC \\
\hline Ibrahim et al (2013) & 90 & Not recorded \\
\hline Geeslin and LaPrade (2011) & 89.5 & 81.5 \\
\hline McCarthy et al (2015) & $\begin{array}{c}\text { Recon. } \\
83 \\
\text { Repair } \\
83\end{array}$ & $\begin{array}{l}68 \\
71\end{array}$ \\
\hline Levy et al (2010) & $\begin{array}{c}\text { Recon. } \\
88 \\
\text { Repair } \\
85 \\
\end{array}$ & $\begin{array}{l}77 \\
79\end{array}$ \\
\hline Schechinger et al (2009) & $\begin{array}{ll}\text { Acute } & 88.7 \\
\text { Chronic } & 89.9 \\
\end{array}$ & $\begin{array}{l}78.1 \\
81.3 \\
\end{array}$ \\
\hline Shelbourne et al (2007) & 91.5 & 91.3 \\
\hline Bin and Nam (2007) & 87.5 & Not recorded \\
\hline Fanelli et al (2014) & 91.8 & Not recorded \\
\hline Kim et al (2013) & 86.3 & Not recorded \\
\hline Kim et al (2012) & 90.1 & Not recorded \\
\hline Kim et al (2011) & $\begin{array}{ll}\text { Group A } & 89.1 \\
\text { Group B } & 82.7 \\
\end{array}$ & Not recorded \\
\hline Kim et al (2010) & 86.6 & Not recorded \\
\hline Zorzi et al (2013) & 89.1 & 86 \\
\hline Noyes et al (2011) & 87.4 & Not recorded \\
\hline Noyes et al (2007) & 85.8 & Not recorded \\
\hline Yoon et al (2011) & 86.4 & 75.3 \\
\hline Jakobson et al (2010) & 90.2 & Not recorded \\
\hline LaPrade et al (2010) & 84.2 & 62.6 \\
\hline
\end{tabular}

Varus stress test: 
Table (4) showing postoperative varus stress results

\begin{tabular}{|c|c|c|c|c|}
\hline & $\mathbf{0}$ & +1 & +2 & Criteria of measurement \\
\hline Ibrahim et al (2013) & 14 & 3 & 3 & Examination \\
\hline $\begin{array}{c}\text { Geeslin and LaPrade } \\
(2011)\end{array}$ & 16 & 5 & 5 & Examination \\
\hline McCarthy et al (2015) & $\begin{array}{ll}\text { Recon. } & 15 \\
\text { Repair } & 13 \\
\end{array}$ & $\begin{array}{c}26 \\
3 \\
\end{array}$ & $\begin{array}{l}2 \\
2 \\
\end{array}$ & Examination \\
\hline Levy et al (2010) & $\begin{array}{cc}\text { Recon. } & 11 \\
\text { Repair } & 3 \\
\end{array}$ & $\begin{array}{l}6 \\
3 \\
\end{array}$ & $\begin{array}{l}1 \\
4 \\
\end{array}$ & Examination \\
\hline $\begin{array}{c}\text { Schechinger et al } \\
(2009)\end{array}$ & $\begin{array}{ll}\text { Acute } & 5 \\
\text { Chronic } & 5 \\
\end{array}$ & $\begin{array}{l}2 \\
4 \\
\end{array}$ & & Examination \\
\hline Shelbourne et al (2007) & 9 & 5 & 7 & Radiograph \\
\hline Bin and Nam (2007) & 5 & 2 & 1 & Radiograph \\
\hline Fanelli et al (2014) & 20 & 12 & 2 & Examination \\
\hline Kim et al (2013) & 31 & 22 & 12 & Radiograph \\
\hline Kim et al (2012) & 13 & 8 & 2 & Radiograph \\
\hline Kim et al (2011) & $\begin{array}{lr}\text { Group A } & 16 \\
\text { Group B } & 5 \\
\end{array}$ & $\begin{array}{c}4 \\
11\end{array}$ & $\begin{array}{l}\text { A } 1 \\
\text { B } 9\end{array}$ & Radiograph \\
\hline Kim et al (2010) & 27 & 13 & 2 & Radiograph \\
\hline Zorzi et al (2013) & 12 & 5 & 2 & Examination \\
\hline Noyes et al (2011) & 8 & 2 & 3 & Radiograph \\
\hline Noyes et al (2007) & 8 & 5 & 1 & Examination \\
\hline Yoon et al (2011) & 21 & 10 & 1 & Examination \\
\hline Jakobson et al (2010) & 9 & 17 & 1 & Examination \\
\hline LaPrade et al (2010) & 48 & 12 & 4 & Examination \\
\hline
\end{tabular}

Objective outcomes were classified as success or failure based on postoperative varus stress examination findings, varus stress radiographs, where Success was defined as grade 0 or I. Failure was defined as grade II or III post-operative or the need to reoperate because of varus instability. That makes the failure rate of repair of acute PLC is $25 \%$ and failure rate of reconstruction of PLC is $9 \%$

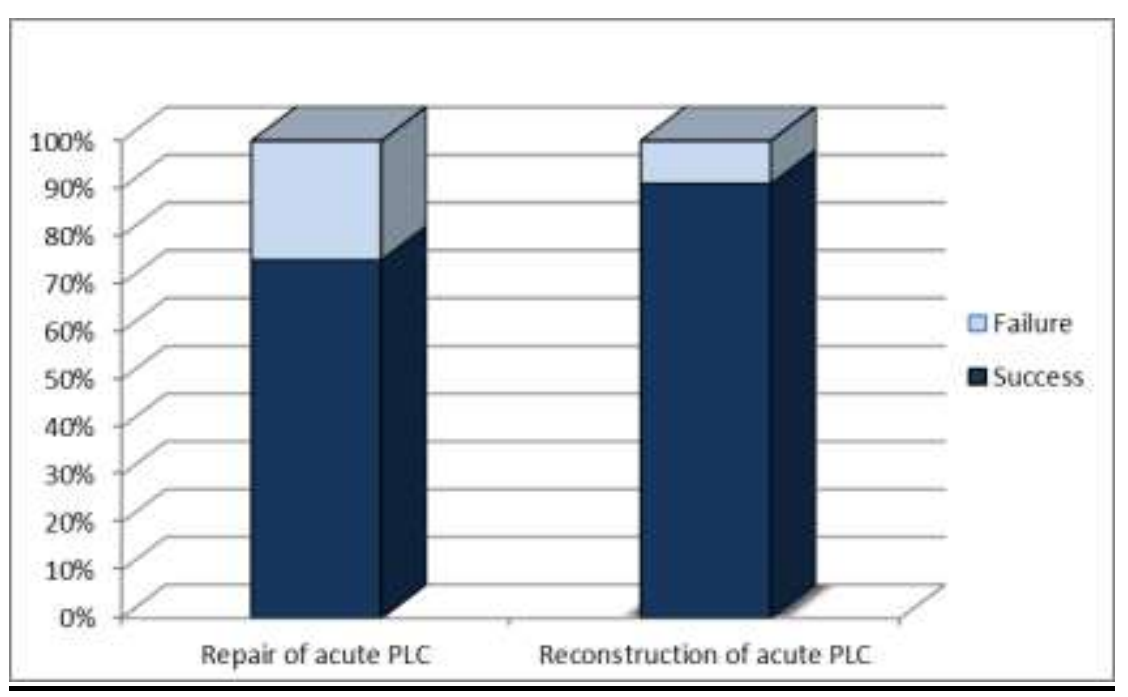

Repair of acute PLC injury is associated with $25 \%$ failure rate.

Reconstruction of acute PLC is associated with $9 \%$ failure.

Success and failure of different reconstruction techniques:

1- Isometric reconstruction of the FCL and the popliteus with a single graft. Success $88 \%$ Failure $12 \%$. 
Anatomic reconstruction of FCL, popliteus and PFL. Success 93\% failure 7\%

Fibular sling with single femoral tunnel. Success $91 \%$ failure $9 \%$

Fibular sling with 2 femoral tunnels. Success $95 \%$ failure $5 \%$.

Modified biceps rerouting tenodesis. Success $65 \%$ failure $35 \%$

\section{Comparison between success rates of different reconstruction techniques:}

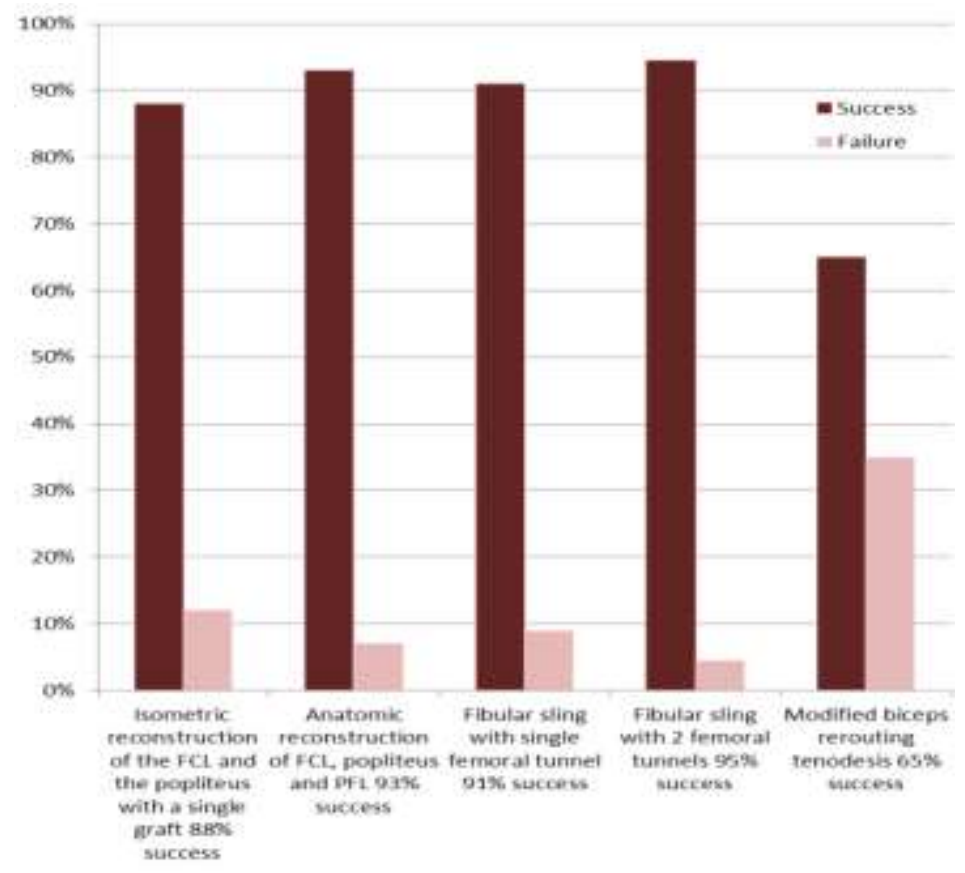

\section{DISCUSSION}

The most evident outcome was that the acute repair of the PLC is associated with $25 \%$ failure rate, and reconstruction of PLC is associated with $9 \%$ failure. Reconstruction techniques varied among studies which can be categorized, all reconstruction techniques had very close failure rates, the highest failure rate was isometric reconstruction of the FCL and the popliteus with a single graft with failure rate $12 \%$ and the lowest one was the fibular sling with 2 femoral tunnels with failure rate $5 \%$. There were several limitations including PLC injuries mostly occur combined with other injuries where 59\% had combined PCL injuries, while only $23 \%$ had combined ACL injuries, 6\% had combined ACL and PCL injuries, and $12 \%$ had isolated PLC injuries, making it difficult to suggest a specific treatment for PLC injuries, no randomized control trials, surgeon's experience affects decision and outcome of the surgical technique, level of evidence in the literature for outcomes after the surgical treatment of PLC injuries limits any definitive conclusions regarding an optimal surgical technique, as with any systematic review, it is possible that relevant articles or patient subgroups were not identified with our search terms and literature review.

\section{CONCLUSION}

Repair of acute PLC injuries was associated with a $25 \%$ failure rate, whereas reconstruction of PLC structures had 9\% failure rate. Reported subjective and objective outcome scores varied across the 15 studies. Surgical techniques included variations of fibular slings, capsular shifts, and 2-tunnel techniques (fibular tunnel and tibial tunnel), anatomic reconstruction. Further research with longer follow up, and randomized control trials is needed to determine the optimal surgical technique for treating PLC injuries because of the wide variability of reported objective and subjective postoperative outcomes.

\section{REFERENCES}

1. LaPrade RF, Wentorf FA, Fritts H, Gundry C, Hightower CD. A prospective magnetic resonance imaging study of the incidence of posterolateral and multiple ligament injuries in acute knee injuries presenting with a hemarthrosis. Arthroscopy 2007; 23(12):1341-7.

2. Diamantopoulos A, Tokis A, Tzurbakis M, Patsopoulos I, Georgoulis A. The posterolateral 
corner of the knee: evaluation under microsurgical dissection. Arthroscopy 2005; 21:826-33.

3. LaPrade RF, Ly TV, Wentorf FA, Engebretsen L. The posterolateral attachments of the knee: a qualitative and quantitative morphologic analysis of the fibular collateral ligament, popliteus tendon, popliteofibular ligament, and lateral gastrocnemius tendon. Am J Sports Med 2003;31:854-860.

4. Fornalski S, McGarry MH, Csintalan RP, Fithian DC, Lee TQ. Biomechanical and anatomical assessment after knee hyperextension injury. Am J Sports Med. 2008; 36:80-84.

5. Levy BA, Dajani KA, Morgan JA, Shah JP, Dahm DL, Stuart MJ. Repair of the fibular collateral ligament and posterolateral corner in the multiligament-injured knee. Am J Sports Med. 2010; 38(4):804-809.

6. Ibrahim SA, Ghafar S, Salah M, et al. Surgical management of traumatic knee dislocation with posterolateral corner injury. Arthroscopy. 2013;29(4):733-741.

7. Geeslin AG, LaPrade RF. Outcomes of treatment of acute grade-III isolated and combined posterolateral knee injuries: a prospective case series and surgical technique. J Bone Joint Surg Am.2011; 93(18):1672-1683.

8. Mark McCarthy, MD, TJ Ridley, MD, Matthew Bollier, MD,Shane Cook, MD, Brian Wolf, MD, Annunziato Amendola, MD. Posterolateral knee reconstruction versus repair, Iowa Orthop J 2015; 35: 20-25.

9. Schechinger SJ, Levy BA, Dajani KA, Shah JP, Herrera DA, Marx RG. Achilles tendon allograft reconstruction of the fibular collateral ligament and posterolateral corner. Arthroscopy. 2009; 25(3):232-242.

10. Shelbourne KD, Haro MS, Gray T. Knee dislocation with lateral side injury: results of an en masse surgical repair technique of the lateral side. Am J Sports Med. 2007;35(7):1105-1116.

11. Bin SI, Nam TS. Surgical outcome of 2-stage management of multiple knee ligament injuries after knee dislocation, Arthroscopy. 2007; 23(10):1066-1072.

12. Fanelli GC, Fanelli DG, Edson CJ, Fanelli MG. Combined anterior cruciate ligament and posterolateral reconstruction of the knee using allograft tissue in chronic knee injuries. J Knee Surg. 2014; 27(5):353-358.

13. Kim SJ, Kim SG, Lee IS, et al. Effect of physiological posterolateral rotatory laxity on early results of posterior cruciate ligament reconstruction with posterolateral corner reconstruction. J Bone Joint Surg Am. 2013; 95(13):1222-1227.

14. Kim SJ, Choi DH, Hwang BY. The influence of posterolateral rotatory instability on ACL reconstruction: comparison between isolated ACL reconstruction and ACL reconstruction combined with posterolateral corner reconstruction. J Bone Joint Surg Am. 2012; 94(3):253-259.

15. Kim SJ, Kim TW, Kim SG, Kim HP, Chun YM. Clinical comparisons of the anatomical reconstruction and modified biceps rerouting technique for chronic posterolateral instability combined with posterior cruciate ligament reconstruction. J Bone Joint Surg Am. 2011;93(9):809-818.

16. Kim SJ, Jung M, Moon HK, Kim SG, Chun Y. Anterolateral transtibial posterior cruciate ligament reconstruction combined with anatomical reconstruction of posterolateral corner insufficiency: comparison of single-bundle versus double-bundle posterior cruciate ligament reconstruction over a 2- to 6-year follow-up. Am J Sports Med. 2011;39(3):481-489.

17. Zorzi C, Alam M, Iacono V, Madonna V, Rosa D, Maffulli N. Combined PCL and PLC reconstruction in chronic posterolateral instability. Knee Surg Sports Traumatol Arthrosc. 2013;21(5):1036-1042.

18. Noyes FR, Barber-Westin SD. Long-term assessment of posterolateral ligament femoralfibular reconstruction in chronic multiligament unstable knees. Am J Sports Med. 2011;39(3):497-505.

19. Noyes FR, Barber-Westin SD. Posterolateral knee reconstruction with an anatomical bone-patellar tendon-bone reconstruction of the fibular collateral ligament. Am J Sports Med. 2007;35(2):259-273.

20. Yoon KH, Lee JH, Bae DK, Song SJ, Chung KY, Park YW. Comparison of clinical results of anatomic posterolateral corner reconstruction for posterolateral rotatory instability of the knee with or without popliteal tendon reconstruction. Am J Sports Med. 2011;39(11):2421-2428.

21. Jakobsen BW, Lund B, Christiansen SE, Lind $\mathrm{MC}$. Anatomic reconstruction of the posterolateral corner of the knee: a case series with isolated reconstructions in 27 patients. Arthroscopy. 2010; 26(7):918-925.

22. LaPrade RF, Johansen S, Agel J, Risberg MA, Moksnes H, Engebretsen L. Outcomes of an anatomic posterolateral knee reconstruction. J Bone Joint Surg Am. 2010;92(1):16-22. 